\title{
Cinema e juventude: uma discussão sobre ética das imagens
}

\author{
Cinema and youth: a discussion about image and ethics \\ Cine y juventud: una discusión sobre la ética de imagen
}

\begin{abstract}
ROSA MARIA BUENO FISCHER* $\diamond$
\end{abstract}

RESUMO - O artigo discute dados de pesquisa recente com jovens estudantes de cursos de Pedagogia, a respeito da sua relação com narrativas da TV, da internet e especialmente do cinema. No tratamento dos dados, debatemos o conceito de imagem, com o objetivo de introduzir nessa discussão a relevante perspectiva do olhar do espectador, dos jogos de olhar que se dão no espaço da cultura, e também dos discursos que circulam, como uma espécie particular de mediação, numa determinada formação social. Com base em Foucault, Didi-Huberman, Badiou e Ismail Xavier, entre outros, e com o recurso a exemplos de narrativas cinematográficas, enfatizamos a "presença ausente" das imagens, uma vez que estas, diferente do que se diz no senso comum, não se apresentam a nós como transparência (pelo contrário, elas sempre carregam forte carga de opacidade). Entendemos que isso tem consequências importantes, dos pontos de vista ético e estético, para a formação docente.

Palavras-chave - Cinema. Imagem. Formação docente. Formação ético-estética.

ABSTRACT - This paper discusses recent research with young students in Pedagogy, about his relationship with narratives of TV, Internet and especially the cinema. We discuss the concept of image, emphasizing the viewer's gaze perspective, looking at the games that take place in the space of culture, and also the discourses that circulate as a particular kind of mediation in a particular social formation. Based on Foucault, Didi-Huberman, Badiou and Ismail Xavier, among others, we emphasize the "absent presence" of images, because images are not presented to us as transparency (on the contrary, they always carry a lot of opacity). We understand that this discussion has important consequences, in terms of ethical and aesthetic education, for children, young people and especially teachers.

Keywords - Cinema. Image. Teacher education. Ethical-aesthetic education.

RESUMEN - El artículo analiza los datos de las investigaciones recientes con jóvenes estudiantes de los cursos de pedagogía, sobre su relación con las narrativas de la televisión, Internet y sobre todo el cine. En los datos, discutió el concepto de imagen, con el objetivo de introducir esta discusión relevante la perspectiva de la mirada del espectador, la mirada de los juegos que tienen lugar en el espacio cultural, así como los discursos que circulan como un tipo particular de la mediación en una formación social dada. Sobre la base de Foucault, Didi-Huberman, Badiou y Ismail Xavier, entre otros, y con el uso de ejemplos de narrativas cinematográficas destacar la "presencia ausente" de las imágenes, ya que éstas, a diferencia de lo que dice el sentido común, no presentarse a nosotros como la transparencia (por el contrario, siempre llevan la opacidad de carga pesada). Entendemos que esto tiene consecuencias importantes, los puntos éticos y estéticos de la vista, para la formación del profesorado.

Palabras clave - Cine. Imagen. La formación del profesorado. La formación ética y estética.

\footnotetext{
* Doutora em Educação pela Universidade Federal do Rio Grande do Sul (Porto Alegre, RS, Brasil) e Professora na Universidade Federal do Rio Grande do Sul (Porto Alegre, RS, Brasil). E-mail: <rosabfischer@terra.com.br>.
} 


\section{NARRATIVAS VISUAIS E JUVENTUDE: UMA DISCUSSÃO SOBRE ÉTICA DAS IMAGENS}

Como pensar as imagens num tempo marcado, cada vez mais, pelo acesso a todo e qualquer tipo de informação, em que a comunicação do que somos e do que desejamos ser é marcada intensamente por figuras, cenas audiovisuais, fotografias, reproduções de desenhos e pinturas, pequenos vídeos - copiados ou criados por nós? De que modo crianças e jovens estão experimentando essas formas de envio de mensagens sobre si mesmos? Que histórias contam ao outro e o que buscam com essas narrativas? Que relevância essas práticas com imagens audiovisuais, permitidas e facilitadas pelo acesso a diferentes tecnologias digitais, teriam para o cotidiano escolar? Dos pontos de vista teórico e político, interessanos igualmente indagar: que conceito de imagem opera nos modos pelos quais construímos e disseminamos cenas e objetos pictóricos? Como falamos deles e de que modo eles passam a fazer parte do que entendemos pelos pares imagem e verdade, realidade e ficção, criação artística e informação? Haveria alguma relação entre imagem e posicionamento ético diante do mundo e da vida? Este texto procura não exatamente responder a tão amplas questões, mas oferecer material de pesquisa e discussão teórica a respeito delas, partindo de dados de uma pesquisa com estudantes de Pedagogia.

Nos últimos oito anos, temos buscado estabelecer relações entre mídia, cultura e juventude, enfatizando, mais especificamente, o estudo sobre como jovens de camadas médias e populares, estudantes de cursos de Pedagogia, realizam suas escolhas e se posicionam quanto à experiência que têm com o cinema e à perspectiva de utilizar esse tipo de narrativa audiovisual nos espaços escolares. Nos levantamentos feitos para a pesquisa sobre cinema e formação ético-estética da juventude, os 585 questionários aplicados a estudantes trouxeram dados extremamente ricos para análise (e estimuladores de novas investigações, certamente). ${ }^{1}$ Ao cotejar esses achados com discussões já feitas por outros estudiosos (da sociologia da juventude, da filosofia da cultura, da psicanálise, da semiologia, da educação), percebemos aproximações relevantes (desses trabalhos com os materiais por nós levantados).

Pode-se dizer que, certamente, os dados nos estimularam a propor outros e novos estudos, a partir dos quais entendemos ser possível problematizar o conceito de imagem, introduzindo nesse debate um tópico que julgamos fundamental: a perspectiva do olhar do espectador e, mais amplamente, os jogos de olhar que se dão no espaço da cultura, numa determinada formação social, e também dos discursos que circulam, como uma espécie particular de mediação nesse processo. Estamos aqui acompanhados de Alain Badiou, Didi-Huberman, Ismail Xavier e Michel Foucault, entre outros, na medida em que esses pensadores nos convidam a enfatizar o que se pode chamar de "presença ausente" das imagens: diferentemente do que circula no senso comum, as imagens (como as do cinema, que nos interessam aqui) não se apresentam para nós como transparência; pelo contrário, elas sempre carregam forte opacidade. Ora, isso tem consequências importantes, dos pontos de vista ético e estético, para a formação de crianças, jovens e também de adultos - especialmente os que se preparam para atuação no magistério.

A esses estudos teóricos sobre imagem articulamos outros trabalhos, relacionados a investigações recentes sobre juventude. Inúmeros são os autores que têm afirmado a importância dos modos de socialização que emergem em meio ao que vem sendo chamado genericamente de "cultura visual", em nossos tempos, associada à aparição de uma "comunidade mundial" - e que tem ligação indiscutível com o amplo acesso às tecnologias digitais de comunicação e informação, especialmente por marte dos mais jovens. Para Jesús Martín-Barbero, os jovens constituiriam hoje "o ponto de emergência de uma cultura outra, que rompe tanto com a cultura baseada no saber e na memória dos mais velhos quanto naquela cujos referentes, ainda que movediços, ligavam os padrões de comportamento dos jovens aos dos pais que, com algumas variações, os buscavam e adaptavam a partir de seus avós" (Cf. MARTIN-BARBERO, 2002, trad. nossa). Essa espécie de empatia dos jovens com a cultura tecnológica, basicamente com os diversos modos de interação e de comunicação, pela internet, falam-nos, segundo o antropólogo, de novos modos de perceber, ver e narrar, a si e aos outros; falam-nos de um outro tipo de relação das gerações mais jovens com uma gama enorme de temporalidades, vividas simultaneamente por esses grupos. ${ }^{2}$

\section{UM PASSEIO PELOS DADOS DA PESQUISA}

Assim, antes de discutir teoricamente os achados da pesquisa aqui referida, convém situar como buscamos os dados e quais deles consideramos mais relevantes. Durante um ano (entre 2009 e 2010), aplicamos um questionário a 585 estudantes de Pedagogia de universidades da região $\mathrm{X}$, públicas e privadas, com questões sobre perfil socioeconômico, razões da escolha do curso, experiências com produtos audiovisuais, especialmente o cinema, hábitos de lazer, atividades culturais, de entretenimento e de acesso a informações. O questionamento principal, no conjunto de 33 perguntas, referiu-se à experiência dos estudantes com o cinema e especialmente às perspectivas que eles veem, como futuros docentes, de utilização 
das narrativas fílmicas na prática cotidiana de sala de aula. Junto ao levantamento por meio de questionário, iniciamos um conjunto de encontros de "recepção", com a apresentação de filmes, e também um conjunto de entrevistas individuais.

Considerando todos os participantes que responderam aos questionários, $95 \%$ são do sexo feminino e $58 \%$ têm entre 19 e 28 anos. Os estudantes estão matriculados em cursos de Pedagogia de seis diferentes universidades (abrangendo 32 municípios e aproximadamente quatro milhões de habitantes). Mais da metade dos participantes ingressou no curso de Pedagogia entre 2006 e 2009; $46 \%$ dos alunos moram com os pais e $37 \%$ com um companheiro ou companheira. Trata-se de um conjunto de pessoas em sua maioria composto por jovens mulheres, com formação escolar predominantemente em instituições públicas de ensino $(75 \%)$ e exercendo algum tipo de atividade profissional $(81 \%$, incluídos aí bolsas ou estágios). Metade deles tem renda familiar mensal de até quatro salários mínimos.

Como principal fonte de entretenimento, os estudantes apontaram a televisão (36,4\%), e a internet (por 33,5\%). Tais fontes também são apontadas como principais veículos de informação (a televisão, apontada por 39\%; a internet, por $31 \%$ dos estudantes). É importante ressaltar também que $59 \%$ dos estudantes que responderam ao questionário afirmaram que assistem TV até duas horas por dia. Quanto ao uso da internet, 45,6\% afirmaram que acessam a rede também até duas horas por dia. Ainda quanto aos hábitos diários, $53,7 \%$ dos alunos afirmaram ler por até duas horas diariamente.

Quando questionados sobre a frequência com que veem filmes, 20,3\% afirmaram assistir até três filmes e $37,6 \%$, um filme por semana; quanto ao veículo utilizado para assistir a filmes, $51,1 \%$ informaram como principal fonte de acesso a televisão; e 34,7 definiram como principal fonte de acesso as vídeo locadoras. Ainda assim, 74,7\% dos estudantes afirmaram que costumam ir às salas de cinema, embora deva-se assinalar como relevante o fato de que $14 \%$ costumam ir ao cinema somente uma vez a cada seis meses. Os gêneros de maior preferência são drama e romance (preferência de 26,3\% dos entrevistados), além das comédias (25\%). O tema e o gênero dos filmes mostram-se muito relevantes para esse grupo, e a grande maioria (65\%) não registra informações sobre o fato de o filme ser deste ou daquele diretor. Da mesma forma, uma boa parte dos alunos não costuma ler nada sobre cinema.

Para nós, além dessas estatísticas, havia uma questão central: afinal, o que os alunos de Pedagogia consideravam um "bom" filme? Um percentual significativo (88\%) informou concordar com a afirmação de que um filme é bom quando "retrata a realidade"; para $82 \%$, um filme é bom quando apresenta situações urgentes da sociedade; $70 \%$ afirmam que um filme é bom quando emociona; $61 \%$ discordam da afirmação de que o bom filme é aquele que tem tudo a ver com as suas vidas e $67 \%$ afirmam que não têm paciência para assistir a filmes lentos demais. Também consideramos importante o fato de que não há unanimidade no que se refere à avaliação que fazem do cinema mais atual e o de épocas mais antigas: 55\% dos alunos concordam em parte ou plenamente com a afirmação de que os filmes hoje são melhores, tanto pelo aperfeiçoamento da técnica quanto pelas temáticas abordadas. Metade dos estudantes afirma que não se produzem filmes bons como antigamente; porém, metade discorda totalmente desse enunciado. $\mathrm{O}$ conjunto de estudantes divide-se quando se trata de avaliar a qualidade dos filmes, a partir da origem geográfica (a nacionalidade das produções fílmicas): $53 \%$ dos estudantes concordam que os filmes europeus são mais "cabeças" do que os americanos, e $52 \%$ discordam que os filmes americanos são melhores, porque seus estúdios teriam mais recursos. No entanto, $51 \%$ dos alunos concordam que os filmes não ocidentais são difíceis de entender.

Presentes no questionário também estavam algumas afirmações sobre o cinema como uma manifestação artística: $62 \%$ dos alunos discordam da afirmação de que o cinema é apenas uma forma de entretenimento; $77 \%$ concordam que o cinema é uma forma de arte, e $55 \%$ afirmam que qualquer tipo de filme pode ser considerado arte; já $92 \%$ dos alunos concordam ainda que um filme pode ser tão rico artisticamente quanto um romance, uma pintura ou uma peça de teatro. Porém, quanto à utilização do cinema na escola, $67 \%$ dos estudantes concordam que o principal objetivo de utilizar filmes na sala de aula é o de ilustrar os conteúdos trabalhados; 79\% dos estudantes concordam que os filmes são uma boa opção para tornar as aulas "menos monótonas". Quanto a essa prática, 97,3\% consideram importante o uso do cinema nas salas de aula, e $97 \%$ afirmam que assistir a filmes é importante para sua formação como futuros docentes; $95 \%$ dos estudantes inclusive afirmaram que o cinema pode proporcionar reflexões sobre questões sociais e existenciais que gerem algum aprendizado.

Os dados estatísticos, a partir de um segundo momento da investigação, passaram a ser problematizados e vistos com mais vagar, a partir de outras estratégias. Uma delas tem sido a da experiência com grupos de recepção: após uma discussão sobre a importância das imagens audiovisuais na formação ética e estética, o grupo tem acesso a um curta-metragem e ao trecho de um filme. A apreciação das imagens e sequências dos filmes é o que inspira o debate, cujo ponto de partida são vivências dos estudantes com o cinema. Num dos encontros realizados, uma aluna declarou: "É mais forte 
que a gente essa questão do pedagógico [...]. Por mais que eu poderia dizer hoje; 'a gente pode usar pela arte', vai chegar em sala de aula, eu não vou conseguir usar o filme só pela arte. Só por ser uma arte, assim, pras crianças, por interação, assim, acabo não conseguindo [...]". Pode-se dizer que essa aluna expõe sua dificuldade, ou sua impotência momentânea, em propiciar momentos de fruição e contato artístico que se contraponham ao mero utilitarismo da produção cinematográfica na escola; ao mesmo tempo, ela expressa um pedido (e até um desejo), relativo à sua própria formação, no sentido de esta voltar-se mais atentamente para as questões éticas e estéticas. Isso está presente em outro conjunto de dados, de entrevistas individuais com estudantes, uma das quais afirma que, como futura pedagoga, desejaria uma formação docente que a convidasse a pensar, para além de técnicas e metodologias, mas também sobre obras artísticas que a impulsionasse a um tipo de transformação e desacomodação (cf. KRALIK, 2012, p. 6).

Em outras palavras: parece haver um vazio ou uma defasagem, entre o que fazem e vivenciam as estudantes e aquilo que também esperam como formação. Parece haver um desejo de abrir espaço para o novo, para o inusitado, para a possibilidade de experimentar o ainda não experienciado. Nos encontros de grupo ou individuais, observamos que algumas alunas, por exemplo, desejam "[...] assistir a um filme, sem expectativa de caminho ou processo com início, meio e fim predeterminados, sem finalidade anteriormente delimitada [...]"; isso, para Kralik (idem), inclui-se na perspectiva de "ir ao encontro da experiência".

O fato é que alguns depoimentos ocorridos durante debates com o grupo de recepção e no decorrer das entrevistas podem ser associados (não como repetição, mas como questionamento) à resposta dada nos questionários, segundo os quais $67 \%$ dos estudantes concordam que o principal objetivo de utilizar filmes na sala de aula é o de "ilustrar os conteúdos trabalhados". Ao contrário, o que foi possível discutir no encontro com os estudantes, ao vivo, foi que há de fato possibilidades de ir adiante e de ampliar (e não limitar) a ação a partir da prática com narrativas fílmicas. Quando assistimos a um trecho ${ }^{3}$ de dez minutos do longa-metragem iraniano Filhos do paraíso, durante a projeção tivemos um momento de silêncio e concentração total entre todos os participantes. Tão logo acenderam-se as luzes, o silêncio permaneceu por algum tempo, até que alguns alunos comunicaram o genuíno desejo de assistir ao filme do início ao fim. "Na verdade eu fiquei muito curiosa. Queria ver o filme todo agora" - disse uma aluna.

O fato de ser um filme de país diferente em relação à maior parte dos filmes já vistos pelo grupo também foi citado: “[...] foge do que a gente está acostumada, né?; os filmes hollywoodianos, aquelas coisas". Impulsionado por esse interesse e surpresa provocados pelo filme, o grupo debateu acerca de várias questões éticas. Dentre as principais falas, destacamos a seguinte: " [...] o cuidado do irmão, por mais que ele, pelo que a gente entendeu aqui, ele não perdeu o tênis por querer, mas a preocupação dele é: 'tu podes ir com o meu tênis'. Ali, pelo menos pela imagem, não tem muita diferença de idade e tu vê uma criança pensar na outra, se ver no lugar da outra. Por mais que ele tivesse perdido, não foi por querer, não era uma obrigação dele oferecer o tênis para a irmã".

Os estudantes também expuseram questões relativas à estética do filme iraniano: "A fotografia é uma coisa bem interessante. A filmagem dele, principalmente na hora das mãos, o foco no caderno, que tu não veria [sic] isso [num filme] nos Estados Unidos, mas essa coisa do foco no caderno e no lápis. Foco nos pequenos detalhes, o pequeno detalhe, ali, da mãozinha". Algumas das técnicas da linguagem cinematográfica que apareceram no filme também foram analisadas pelo grupo. "E é tão legal isso do cinema assim, fazer uma comunicação sem som. E isso é uma sensação que a gente tem. Porque pra nós tem som. A gente ouve as vozes, só que na cena não" (idem).

Enfim, estávamos diante de acontecimentos que não apresentam um caminho único e predefinido, mas que são frequentemente desejados nos ambientes de formação - debate sobre questões éticas, inspirações para a educação do olhar, diálogos sobre as técnicas da linguagem audiovisual. Tais acontecimentos podem emergir como decorrência do contato de um grupo com cinema e até mesmo com um trecho de um filme, como no caso dessa primeira situação relatada. Porém, nessa ocasião, o grupo de recepção proporcionou diálogos que apontavam diretamente para a questão da formação docente. Da mesma forma, nas entrevistas individuais, uma integrante do grupo de pesquisa indagou a suas colegas se, como professoras, levaria esse filme (Filhos do paraíso) para crianças assistirem em um ambiente escolar. Primeiramente, as alunas responderam de forma negativa. "Eu acho que não. Eu achei muito triste [...]". "[...] não é atrativo, eu acho que é mais adulto, pra prestar atenção e entender a importância, pra segurar, pra prender a criança a assistir". "Acho que é uma linguagem feita para adulto". "[...] acho que as crianças não, nessa faixa etária não teriam como fazer essa relação, e, até porque as crianças de hoje estão acostumadas com um outro nível de imagem. As imagens [agora] são muito rápidas. E aí, tu tem [sic] que pensar: é uma coisa mais lenta. Então não seria atrativo pra eles." Aos poucos, porém, elas foram pondo em dúvida sua certeza sobre não levar o filme para assistir com os alunos. Falaram de experiências com crianças de Educação Infantil, utilizando filmes antigos, em preto e branco, e observaram o quanto os alunos se 
envolveram. Chegaram, então, à conclusão: "Eu acho que a gente pode passar esse filme [Filhos do paraíso]. [...] Até porque as crianças nos surpreendem muito [...] elas vão fazer as relações delas".

A limitada relação entre as futuras docentes e o cinema - conforme os dados da aplicação dos questionários - vai desde a explicitação do porquê das escolhas que fazem em relação ao cinema, até mais especificamente a constituição de um repertório acerca das produções fílmicas. Um dos itens do questionário solicitava que fossem citados três filmes considerados por elas muito bons. Dentre os dez filmes mais citados, nove têm como país de origem os Estados Unidos. ${ }^{4}$ Mais especificamente, são produções dos estúdios hollywoodianos - Warner Bros, Paramount e Columbia Pictures. Poderíamos dizer que os questionários apontam uma reduzida experiência com filmes que estejam fora do circuito de uma produção maciçamente veiculada nos canais de TV e predominantemente presente nas salas de cinema e nas prateleiras das locadoras.

É perceptível, portanto, a existência de uma relação bastante restrita entre o cinema e os alunos de Pedagogia, tanto nas respostas ao questionário, sobre suas experiências subjetivas com filmes quanto nas opções escolhidas e no que se refere ao uso que imaginam fazer do cinema na escola. Quando indagados sobre a importância dos filmes em sala de aula, mais do que o tom utilitarista da arte cinematográfica na escola, talvez o que chame a atenção é a percepção e o entendimento do que seria a "verdade" e a "realidade" das imagens, seja no sentido de os estudantes buscarem a "verdade dos fatos" em filmes e outras narrativas audiovisuais, seja nas concepções que manifestam quanto à utilização das imagens audiovisuais na escola, com o objetivo de tornar o ensino "mais concreto", "mais agradável" ou "mais próximo da realidade do aluno" - só para citar as respostas recorrentes dos entrevistados.

A insistência e a reiteração da afirmação da imagem como "retrato da realidade", nos encontros com os estudantes, a grande maioria deles mulheres na faixa de idade de 17 a 30 anos, provoca-nos a ampliar os estudos sobre o grande tema das relações entre imagem e verdade, tendo como foco de atenção, novamente, jovens estudantes de Pedagogia. Em termos mais amplos, poder-se-ia dizer que os resultados da pesquisa nos convocaram a continuar os estudos sobre imagem, juventude e formação éticoestética; ou seja, serviram como mote para novos estudos.

\section{VERDADE DAS IMAGENS OU FICCIONALIZAÇÃO DO REAL?}

Afinal, o que sucede na nossa relação com a "realidade", ou com a "verdade dos fatos" quando temos o acesso a narrativas visuais, como as da televisão e do cinema? Pergunto: nosso desejo (e o dos nossos estudantes) é ver "a nossa vida" reproduzida ali, ou nos agrada principalmente o fato de nos depararmos com alguma suposta realidade, que julgamos por vezes ser a "verdadeira realidade"? Enfim, como existem para os universitários de nossa pesquisa as imagens audiovisuais: como cópias da realidade, como imitação do vivido, como reprodução daquilo que "já existe", como ficção, como invenção, como metáfora? Para os jovens - e pensamos aqui especialmente nos jovens estudantes de Pedagogia, que se preparam para atuar como docentes -, como é sua relação com as imagens, a que têm acesso quase infinitamente pela internet? Como poderíamos caracterizar, mais detalhadamente, a referência que fazem às imagens do cinema como "um retrato da realidade". Como caracterizam eles essa "realidade", que supostamente estaria de alguma forma presente em filmes que citam como os mais significativos para eles, nos últimos tempos - por exemplo, Tropa de elite, Se eu fosse você ou $O$ mistério da libélula?

Como se vê por esses poucos exemplos, os filmes indicados como seus preferidos são construídos em muito diversos estilos de narrativa; no entanto, em relação a essas diferentes narrativas, os jovens teceram observações que, quase sempre, os conduziam a avaliar positivamente um filme porque: "retrata uma realidade brasileira", "é uma lição de vida", "é uma história real", "mostra a realidade para a qual estamos direcionando o planeta", "nos remete a uma reflexão de ser humano", nos ensina "a conviver e respeitar as diferenças", é uma história pela qual "muitos já passaram".

Queremos aqui pontuar a relevância desses dados, em se tratando de estudantes de Pedagogia, jovens urbanos que, mesmo diante das mais diferentes produções, insistem, a maioria deles (mais de 90\%), em estabelecer elos diretos com a vida cotidiana ou com a chamada "realidade"; ao mesmo tempo, ao cinema (considerado por eles como bom) é atribuída a qualidade de nos fazer refletir, de necessariamente nos ensinar algo. Como nos diz Foucault, é preciso arrancar esses dados e unidades de sua condição de "quase-evidências", reconhecendo que não se trata de algo tranquilo - e sim de um conjunto dado (ou uma determinada unidade) que nos exige uma ação quase como a de um terremoto; trata-se de sacudir os dados, as coisas faladas, as imagens produzidas. E eu diria, em relação aos dados da pesquisa com os estudantes, que se trata de sacudir tais enunciações, abri-las, arrancálas mesmo da tranquilidade morna em que aparecem. Para quê? Para liberar os problemas que elas colocam (cf. FOUCAULT, 2009, p. 29), pois que elas mesmas já vêm como um feixe de novas questões, as quais merecem ser pensadas. E para isso exige-se uma teoria - um corpo conceitual que dê conta "dos fatos do discurso a partir do 
qual [as unidades] são construídas" (idem). Obviamente não estou confundindo "unidades" com "dados" de uma pesquisa. Interessa aqui a atitude científica proposta por Foucault: desconfiar do que é dado, não para descartá-lo como inútil ou sem sentido; mas exatamente ao contrário: para pensá-lo, para buscar as leis de sua construção, para deixar livres e de algum modo visíveis os problemas que, no nosso caso, um conjunto de enunciações feitas por nossos jovens, tratam dos modos de eles se relacionarem com obras de ficção (como as narrativas cinematográficas), seja como espectadores comuns, seja como estudantes, seja ainda como futuros docentes do Ensino Fundamental. Seguindo ainda Foucault: há que se acompanhar ou tomar essas enunciações como uma "dispersão de acontecimentos e na instância própria de cada um"; trata-se de descrever esses acontecimentos discursivos "como horizonte para a busca das unidades que aí se formam" (idem, p. 30).

Ora, quando confrontamos as respostas dos estudantes sobre o cinema como "ilustração de conteúdos" e como "retrato da realidade" com os trabalhos de autores como Ismail Xavier, nos colocamos justamente diante de uma outra proposta: no livro $O$ olhar e a cena, o autor sublinha que "[a] imagem que recebo compõe um mundo filtrado por um olhar exterior a mim, que me organiza uma aparência das coisas, estabelecendo uma ponte mas também se interpondo entre mim e o mundo" (XAVIER, 2003 , p. 35, grifos nossos). Trata-se de um olhar exterior; no caso do cinema, estamos nos referindo à câmera, que captura a imagem e que, por sua vez, passa a existir num determinado filme. Xavier chama a atenção para todo o trabalho de enquadramento das imagens, para as molduras, enfim; ou seja, fala das escolhas do diretor do filme, que sempre carrega consigo uma determinada perspectiva. Essa nova forma de "organizar uma aparência das coisas" é, em outras palavras, criação e ocupa o espaço entre nós e o mundo. O cinema, assim como a literatura e outras artes, são formas de organizar o "real" e opera como uma das mediações entre nós e aquilo a que assistimos.

Wim Wenders (2005) igualmente nos move a pensar que qualquer filme acaba sempre por abrir-se a muitas possibilidades, desde sua concepção, desde o "sonho" do diretor, até o contato efetivo com o público. Trata-se sempre de um processo que se modifica continuamente, inclusive pelo fato radical de, depois de a obra ser concluída, ela ainda permanecer aberta, pois não haveria como fechar-se como "posse" única e indivisa do autor (diretor): no mínimo, há uma continuidade dela na vida de cada um dos espectadores. O filósofo Jacques Rancière, por sua vez, aponta a urgência de pensarmos e vivermos a necessidade da arte e da ficção (diferente da busca desenfreada pela "realidade" e pela "verdade" das imagens): ao afirmar que "o real precisa ser ficcionado para ser pensado" (2009, p. 58), ele nos oferece um poderoso argumento, para debater "a razão dos fatos" e a "razão da ficção", quando estudamos cinema e educação, imagem e formação docente.

Os autores acima referidos propõem que o cinemaeducação é aquele que faz pensar, que nos desacomoda, que desvia nosso olhar daquilo que é esperado, como clichê ou como fórmula já sabida (cf. XAVIER, 2008). A experiência com a arte aponta para uma educação do olhar, que, na proposta de Jan Masschelein (2008), não tem como objetivo "conscientizar" e sim despertar e libertar a visão, conduzindo-nos para fora (da própria imagem cinematográfica e, diríamos, de nós mesmos). Educar o olhar poderia ser pensado, enfim, como o gesto de nos tornarmos atentos, de caminhar pela mão das imagens, sem nos precipitarmos na busca de verdades supostamente, num "final feliz", numa polarização do caráter ético dos personagens, na chegada consoladora de algumas conclusões já anunciadas, e assim por diante. Fruir o cinema na escola ou fora dela nada tem a ver com "aplicar imagens a conteúdos didáticos": é um convite à surpresa, ao novo, ao diverso, àquilo que não sabemos.

\section{Pedagogia das imagens?}

Dedicamos um bom espaço deste artigo à apresentação de dados estatísticos de uma investigação com quase 600 estudantes de Pedagogia. Interessanos a operação sobre esses dados e uma possibilidade futura de intervenção, junto a esse grupo de pessoas que desejam "ser professores". Um dos trabalhos iniciais, justamente, diz respeito a abrir a expressão "pedagogias das imagens", para pensá-la aceitando enfrentar o primeiro e mais intrigante problema que ela nos traz: o que se refere à relação entre imagem e conhecimento e entre imagem e verdade. A operação sobre imagens parece assemelhar-se ao que muitas vezes ocorre com a literatura na escola: consistiria em esgotar a própria experiência da leitura (ou, no caso dos filmes, esgotar e minar a própria fruição das sequências fílmicas) com sua excessiva e insistente didatização. Afinal, como se indaga a pesquisadora argentina Inés Dussel $(2009$, p. 191), que tipo de conhecimento (e que experiência estética) nos é propiciado pelas imagens audiovisuais? As respostas aos questionários estariam por demais marcadas pelo lugar de onde falam os estudantes de Pedagogia? Ou seja, quando eles reivindicam uma função de "retrato da realidade" para as narrativas do cinema, ou de "lições para a vida", isso teria a ver com um modo mais amplo de relação dos jovens com produtos audiovisuais ou seria próprio do lugar que ocupam na universidade, em faculdades de Educação? 
Deixemos tais questões em suspenso e voltemos a pensar sobre o próprio conceito de imagem. De início, é importante sublinhar: não podemos falar em imagens por si mesmas. Elas existem, no mínimo, na medida em que um espectador tem acesso a elas. $\mathrm{O}$ espectador do cinema é alguém que vive experiências de "imagens com imagens". Segundo o filósofo Alain Badiou, o que temos, num filme, são "imagens das imagens, e essas imagens não são o filme. São a relação com o filme e, portanto, ao fim e ao cabo, relações entre as imagens" (2004, p. 59-60, trad. e grifos nossos). Elas são, em suma, a matéria-prima com a qual o cinema pensa. Da mesma forma, pode-se dizer que elas existem dentro de "regimes visuais" (ou dentro de regimes de verdade, como diria Foucault). Tais regimes, ambos, definem para nós o que é visível e o que é invisível, que posições os sujeitos devem assumir, na condição de sujeitos que veem e de sujeitos que são vistos. Em suma, imagens constituem, sobretudo, relações; imagens são práticas sociais (cf. DUSSEL, 2009, p. 191). Quando nossos estudantes citam como bom o filme de animação Procurando Nemo e justificam afirmando que "precisamos conviver com as diferenças e respeitá-las", essa simples informação nos remete imediatamente a uma série de enunciados de nosso tempo. Ou seja, estamos diante de forças que acabam por produzir narrativas como as do exemplo; mais do que isso, forças discursivas que nos fazem sujeitos de afirmações sobre o respeito às diferenças - ditos que não apareceriam, dessa forma, se a pesquisa fosse feita algumas décadas atrás.

"O que torna a aprendizagem humana singular não é a assimilação direta da realidade, mas o contato e a troca com outras consciências e sensibilidades" (CARRANO, 2005, p. 156). Paulo Carrano aponta a importância da "educação dos sentidos", a atenção ao corpo jovem e as possibilidades de criação e de inscrição no social, de meninos e meninas do meio urbano brasileiro. As diferentes tribos sejam elas de rappers ou de funkeiros, e as novas práticas dos jovens com o uso e a percepção do tempo e com a urgência "do aqui e do agora" - já que o futuro lhes é incerto - anunciam novas formas de subjetividade jovem, as quais, por sua vez, demandam um outro tipo de trabalho nas escolas, por parte dos professores, quanto à educação ética e estética dos alunos. Ora, quando observamos a demanda por "realidade", estaríamos diante da manifestação de uma urgência do tempo presente? E, quem sabe, tal urgência teria relação com uma carência, em termos de formação estética desses mesmos jovens?

As experiências com imagens audiovisuais - que entendemos participarem significativamente da formação estética e ética dos sujeitos -, encontram-se fortemente marcadas pelo acesso predominante dos jovens a produtos do cinema hollywoodiano, com seus "filmes de ação", melodramas e cinema de animação infantil, entre outros. Longe de julgamentos apressados sobre tais produções hegemônicas, propomos que não só estas precisam ser analisadas, em termos de sua linguagem audiovisual e de construção narrativa, como também que aos estudantes é fundamental que sejam oferecidas outras opções, no sentido da ampliação de suas referências e repertório. Parece-nos básico que os alunos exponham aquilo a que têm acesso e, principalmente, aquilo que aprenderam a querer, que lhes dá prazer, aquilo que os interpela fortemente.

Nossos levantamentos são feitos com esse propósito também. Mas queremos ir adiante, para não permanecer no círculo vicioso da constituição de um certo "padrão de gosto estético": tenho acesso a isto, aprendo a gostar disto e passo a desejar um pouco mais - justamente, "disto aqui". Mais uma vez, nossa concordância com Inés Dussel: as imagens são práticas sociais, funcionam dentro de uma certa discursividade. Mas isso não nos leva de modo algum à paralisação; pelo contrário, convidanos a pesquisar essa condição específica das imagens (de relação, de prática, de algo que faz parte de um certo regime de verdade e de visibilidade), junto com o estudo da especificidade das narrativas visuais (particularmente, do cinema). Mais do que isso, somos incitados a pensar as imagens por dentro do campo educacional e da sociologia da juventude, entendendo que esse tipo de produção simbólica, como tudo o que é da ordem do humano, não está, nunca, plenamente "dado". Nem os estudantes precisam ver reduzidas suas experiências com o cinema, nem suas enunciações sobre cinema e "retrato da realidade" constituem fatos consumados. Tais dados estão aí para serem abertos e pensados, na complexidade que lhes é própria.

\section{UM OLHAR PARA ADIANTE...}

Os dados aqui apresentados, em articulação com os debates teóricos que norteiam nossos estudos, têm-nos sugerido o estabelecimento de alguns parâmetros para a escolha dos filmes que poderiam ser exibidos a estudantes de Pedagogia, com foco no objetivo de sua formação ético-estética. Insistimos naquilo que entendemos constituir condição básica da imagem: a de que ela supõe sempre uma relação. Isso significa deixar de lado a separação entre espectador e tela, entre o sujeito que olha (e também o sujeito que cria) e as imagens produzidas. Não se trata de dois campos opostos e isolados. Só haverá efetivamente um "acontecimento-imagem" na medida em que aquela imagem lá estiver sendo fruída por alguém. O que acontece nessa relação é o que vai nos dizer efetivamente algo da imagem. Com isso, assumimos a posição teórica de Didi-Huberman (1998): ele nos diz que 
sempre, de alguma forma, aquilo que vemos também nos olha. Mais do que isso, para esse autor, há que se enfrentar as imagens, "apesar de tudo" (2004).

Como bem assinala Corinne Enaudeau (1999, p. 21, trad. nossa), não existiria "outra realidade, outro sujeito nem outro objeto senão aqueles que resultam do jogo dos olhares e dos discursos que os colocam em cena". Esse jogo tem a ver com uma presença que é ausente, por mais paradoxal que isso nos possa parecer. O que está ali, nas imagens, seria a própria afirmação de que "não estamos lá" naquela cena, não "possuímos" aqueles personagens, nem aquelas falas. Haveria uma fragilidade não só das coisas, de seus rastros, mas também das palavras e das imagens que usamos e inventamos, para falar daquelas mesmas coisas. Por sua vez, Gagnebin (2009, p. 47) escreve sobre a luta contra o esquecimento e a denegação (de horrores como o holocausto), exatamente pela via da narração, num paradoxal trabalho de "transmitir o inenarrável". Gostaríamos de introduzir nesse debate também a dimensão do maravilhoso, das coisas amáveis tão inesquecíveis talvez como os horrores da perseguição e destruição nazistas, e igualmente merecedoras de que se fale delas, em (e a partir de) romances, poemas, filmes. Nisso, a nosso ver, residiria a condição da arte e da criação, como resistência.

Seguindo esses rastros teóricos que afirmam a "presença ausente" das imagens, entendemos que se trata, sempre, de buscar o invisível dentro do visível; é por isso que nos interessam os filmes que, em sua construção narrativa, deixam ao espectador alguns espaços vazios, nos falam de algo não existente, dentro de algo que é parte de nossas existências "concretas". Ao invés de insistirmos, teimosamente, em permanecer nas narrativas cujas linhas de força são as formas imediatas de reconhecimento do bem e do mal, da virtude e do pecado, talvez pudéssemos oferecer, nos cursos de Pedagogia, um conjunto diverso de materiais audiovisuais, que pudessem permitir aos estudantes um modo de fugir das metáforas óbvias, dos lugares-comuns, daquilo que se alimenta do mero recurso melodramático das histórias e que aprendemos a fruir com maior facilidade. Talvez estejamos subestimando a nós mesmos e às crianças e jovens, do Ensino Fundamental e Médio, quando supomos, de antemão, que tal ou qual narrativa será para eles de "difícil apreensão". A harmonia narrativa, sob a forma da linearidade causal das cenas e da própria construção do roteiro para nós fica em segundo ou terceiro plano. Como nos sugere Robson Loureiro (2008), talvez precisemos de um pouco mais de contato com dissonâncias e fragmentações, com ritmos diversos daqueles a que estamos acostumados na prática diária e que estão presentes de modo tão claro no cotidiano escolar.

Diferentemente da prática de buscar "o que o autor quis dizer", quando diante de obras de arte (poemas, romances, pinturas, desenhos, filmes), no afã de decifrar enigmas da criação artística, talvez o que estejamos precisando seja exatamente o contrário: dispor-nos a enfrentar enigmas, entregando-nos a eles e aceitando que, muitas vezes, não há o que decifrar; há que se viver a beleza daquilo que "não nos diz tudo" tão claramente assim. Por isso, fazemos a proposta de ampliação do repertório de estudantes de Pedagogia, para além daquilo a que esse grupo já está acostumado; da mesma forma, além da diversificação do que se vê, propomos o olhar crítico diante das interpretações que focam nas polarizações entre essência e aparência, entre realidade e ficção, entre pessimismo e otimismo, e assim por diante. Tais dicotomias podem ser encontradas não só em produções de grande repercussão (como Titanic, por exemplo), mas igualmente no próprio modo de cada um colocar-se, diante das imagens.

Por essas razões, nos dispomos a ver e debater filmes que incomodam e provocam o espectador, partindo da ideia de que tais obras não temem tocar os "espinhos em nossa carne", como escreve Marilena Chauí (1999); ao contrário de imagens que ferem pela violência explícita e que operam muitas vezes para alívio imediato de nossas dores ou até para pura excitação (como nos filmes de ação, de destruição gratuita de pessoas e objetos, do tipo da série Conan, o bárbaro; ou Conan, o destruidor), interessam-nos obras como as criações de Wim Wenders e de Michael Haneke. ${ }^{5}$ Estas nos incitam a olhar para os perigos de nosso tempo (cf. FOUCAULT, 1995), sem que ofereça no fio narrativo um conjunto de sequências já esperadas ou anunciadas desde a primeira cena, sem que haja descanso e consolação, quando se chega ao final e as luzes acendem. O espinho tocou nossa carne e somos convocados e pensar, a ir adiante, existencial e eticamente.

Neste trabalho educacional com imagens do cinema, nosso intuito é o de fugir às aplicações fáceis, como a de buscar na arte cinematográfica uma espécie de confirmação de verdades historicamente construídas sobre nós mesmos, por exemplo, sobre o conceito de infância, tão caro aos currículos de cursos de Pedagogia. Inspirados em pesquisas como a realizada por Fabiana Marcello (2008), nosso interesse recai sobre a fruição e o debate em torno de personagens-acontecimento e de cenasacontecimento, que o cinema pode nos oferecer. Não se deseja a busca da imagem que reforça um saber construído historicamente a respeito da criança, por exemplo, num campo como o da psicologia, tão próximo do universo da educação; busca-se, sim, uma entrega ao que nos sucede como experiência ética e estética, como entrega ao que é da ordem do conhecido e, simultaneamente, do desconhecido, do que é "nosso" e, ao mesmo tempo, "do outro". 
Valemo-nos de Alain Badiou (2004) para concluir este esforço por tratar o cinema e a imagem como criação, como algo a se fazer, porque sempre estão em jogo "outros", além de um diretor, de um ator, de um roteirista, de um personagem. Estão em jogo muitos outros, carne e osso da própria narrativa e dos mundos por ela habitados. Com Badiou, aprendemos que o cinema apresenta-se genuinamente como meio de nos apresentar o outro na sua relação com o mundo; mais do que isso, o cinema seria para nós um meio muito palpável e rico de amplificar nossas possibilidades de pensar o outro. Na medida em que estamos voltados para uma formação ética e estética de nós mesmos, e, nessa perspectiva de cinema que assumimos, cresce em importância de afirmar (e trabalhar em direção a) que a formação dos educadores pode passar por um contato diferenciado e complexo, com filmes que rompam com os clichês e ampliem nosso repertório artístico e cultural.

$\mathrm{Na}$ pesquisa aqui referida e nas discussões teóricas que os dados suscitaram, articulamos filosofia, cinema e educação. Claramente, fazemos escolhas (de filmes, de formas de tratar tais narrativas junto a professores em formação, de referenciais teóricos). Aliás, todo ato filosófico exige escolhas, nos coloca diante de conflitos, exige-nos certos distanciamentos e posicionamentos. Atos filosóficos têm relação direta com atitudes éticas e estéticas que assumimos. Talvez a mais radical dessas atitudes seja a de, por meio do contato com narrativas fílmicas, aceitarmos viver na descontinuidade e na surpresa, aceitarmos a presença radical do "outro" em nossas vidas e na nossa relação com o mundo social. Da mesma forma, pensar a presença-ausente das imagens, para além de vê-las como replicação da chamada "realidade", tem consequências importantes quando pensamos nas práticas de jovens com o arsenal de imagens, propiciadas pelo acesso às tecnologias digitais e a todas as formas de informação e comunicação em jogo em nosso tempo.

\section{REFERÊNCIAS}

ARENDT, Hannah. A condição humana. Rio de Janeiro: Forense, 2000.

ABRAMO, Helena Wendel. Condição juvenil no Brasil contemporâneo. In: ABRAMO, Helena Wendel; BRANCO, Pedro Paulo Martoni (Org.). Retratos da juventude brasileira: análises de uma pesquisa nacional. São Paulo: Instituto Cidadania; Fundação Perseu Abramo, 2005.

BADIOU, Alain. El cine como experimentación filosófica. In: YOEL, Gerardo (Comp.). Pensar el cine 1: imagen, ética y filosofia. Buenos Aires: Manantial, 2004. p. 23-81.

CARRANO, Paulo. Redes Sociais. In: NOVAES, Regina Reyes; PORTO, Marta; HENRIQUES, Ricardo (Org.). Juventude, cultura e cidadania. Rio de Janeiro: ISER, 2002. v. 1, p. 91-106.
CARRANO, Paulo. Identidades juvenis e escola. In: UNESCO. Construção coletiva: contribuições à educação de jovens e adultos. Brasília: UNESCO/MEC; RAAAB, 2005. p. 153-163.

CHAUÍ, Marilena. Janela da alma, espelho do mundo. In: NOVAES, Adauto (Org.). O olhar. São Paulo: Cia das Letras, 1999. p. 31-63.

DIDI-HUBERMAN, Georges. O que vemos, o que nos olha. Rio de Janeiro: Ed. 34, 1998.

Imágenes pese a todo: memoria visual del holocausto. Trad. Mariana Miracle. Barcelona: Paidós, 2004.

DUSSEL, Inés. Escuela y cultura de la imagen: los nuevos desafíos. Nomadas, Univ. Central Colombia, n. 30, p. 180-193, abr. 2009.

ENNAUDEAU, Corinne. La paradoja de la representación. Trad. Orge Piatigorsky. Barcelona: Paidós, 1999.

FOUCAULT, Michel. A arqueologia do saber. Rio de Janeiro: Forense Universitária, 2009.

Sobre a genealogia da ética: uma revisão do trabalho. In: DREYFUS, Hubert; RABINOW, Paul. Michel Foucault, uma trajetória filosófica: para além do estruturalismo e da hermenêutica. Rio de Janeiro: Forense, 1995.

GAGNEBIN, Jeanne-Marie. Lembrar escrever esquecer. Rio de Janeiro: Ed. 34, 2009.

KRALIK, Gabriela Schumacher. Pequena Miss Sunshine: diálogos possíveis entre cinema e educação. TCC, Curso de Pedagogia, UFRGS, 2012.

LOUREIRO, Robson. Educação, cinema e estética: elementos para uma reeducação do olhar. Educação \& Realidade, v. 33, n. 1 , p. $135-154,2008$.

MARCELLO, Fabiana de Amorim. Criança e imagem no olhar sem corpo do cinema. Tese de Doutorado. Porto Alegre, PPGEDU/UFRGS, 2008.

MARTÍN-BARBERO, Jesús. Jóvenes: comunicación e identidad. Pensar Iberoamérica - Revista de Cultura, OEA, fev. 2002. Disponível em: $<$ http://www.oei.es/pensariberoamerica/ ric00a03.htm>. Acesso em: 10 ago. 2010.

MASSCHELEIN, Jan. E-ducando o olhar: a necessidade de uma pedagogia pobre. Educação \& Realidade, v. 33, n. 1, p. $35-48,2008$.

RANCIÈRE, Jacques. A partilha do sensível. Trad. Mônica Costa Netto. Rio de Janeiro: Ed. 34, 2009.

SARAIVA, Carola Freire. Crianças no cinema e na escola: espaços para o pensamento e a imaginação. In: SEMINÁRIO INTERNACIONAL ENSINO DE ARTES: CULTURA VISUAL, ESCOLA E COTIDIANO, 1., 2012, Pelotas (RS): UFPEL, 2012.

SETTON, Maria da Graça Jacintho. A particularidade do processo de socialização contemporâneo. Tempo Social, v. 17, n. 2, p. 335-350, 2005.

SPOSITO, Marília Pontes (Coord.). Estudos sobre juventude em educação. Revista Brasileira de Educação, São Paulo, n. 5/6, p. 37-52, maio/dez. 1997 (Número especial sobre Juventude e Contemporaneidade).

XAVIER, Ismail. Cinema: revelação e engano. In: . $\mathbf{O}$ olhar e a cena. São Paulo: Cosac \& Naify, 2003. p. $\overline{31-57 .}$ 
XAVIER, Ismail. Um cinema que "educa" é um cinema que (nos) faz pensar. Entrevista. Educação \& Realidade, v. 33, n. 1, p. 13-20, 2008.

WENDERS, Wim. El acto de ver: textos y conversaciones. Trad. de Héctor Piquer. Barcelona: Paidós, 2005.

\section{FILMES CITADOS}

Amor (Dir. Michael Haneke, França, 2012.

Conan, o bárbaro (Dir. John Milius, EUA, 1982).

Conan, o destruidor (Dir. Richard Fleischer, 1984).

Filhos do paraíso (Dir. Majid Majidi, Irã, 1998).

Invisibles crimes (Dir. Wim Wenders, 2007).

O mistério da libélula (Dir. Tom Shadyak, Alemanha/EUA, 2002).

Procurando Nemo (Dir. Andreww Stanton e Lee Unkrich, EUA, 2003).

Se eu fosse você I e II (Dir. Daniel Filho, Brasil, 2006 e 2009).

Titanic (Dir. James Cameron, EUA, 1997).

Tropa de elite I e II (Dir. José Padilha, Brasil, 2007 e 2010).

\section{Notas}

1 No caso de nossa pesquisa atual, os questionários foram preenchidos por 410 alunos de até 30 anos, e por 175 com mais de 30 (total: 585), de seis instituições de Ensino Superior.

2 Ver a propósito estudos de pesquisadores como Paulo Carrano (UFF), Marília Sposito e Maria da Graça Setton (USP), Helena Abramo. Ver: ABRAMO, 2005; CARRANO, 2002; 2005; SPOSITO, 1997; SETTON, 2005.

3 Na cena projetada víamos, em uma peça de uma casa, duas crianças irmãs, protagonistas do filme, comunicando-se através de escritos em cadernos para evitar que os pais soubessem o conteúdo de sua conversa. Podíamos ver também os pais e o irmão bebê que também apareciam na cena, na maior parte do tempo, em segundo plano. No diálogo das crianças, o menino contava à irmã que havia perdido o único sapato dela e, então, lhe fazia a proposta de que os dois dividissem o seu tênis, único sapato do menino também, até que ele achasse uma solução para o problema. Assim, os pais não ficariam sabendo do acontecido. A menina aceita a proposta, ao fim do diálogo escrito e silencioso, que tem como som "de fundo" a conversa dos pais.

${ }^{4}$ Apenas um dos filmes citados não segue essa característica. Este tem como país de origem o Brasil e, mais precisamente, a Globo Filmes, diretamente ligada a uma das grandes redes de televisão aberta do Brasil.

5 Lembramos aqui alguns filmes como o curta Invisibles crimes, de Wim Wenders (segmento do documentário dirigido por Javier Bardem, Invisibles, de 2007); Amor, de Haneke (2012).

Artigo recebido em setembro 2013

Aprovado em novembro 2013. 